\title{
Pengaruh Penerapan Model Pembelajaran Two Stay Two Stray (TS-TS) Terhadap Hasil Belajar Matematika Ditinjau Dari Kecerdasan Matematis- Logis Siswa
}

\author{
Syahriana $^{1)}$, Muhammad Rusydi Rasyid ${ }^{2)}$, Andi Dian Angriani ${ }^{3)}$ \\ 1,2,3Fakultas Tarbiyah dan Keguruan UIN Alauddin Makassar \\ Syahriana114017@yahoo.com ${ }^{1)}, \underline{\text { mrusydi1972@gmail.com }}{ }^{21}$, dian.angriani@uin-alauddin.ac.id ${ }^{3)}$
}

\begin{abstract}
Abstrak
Penelitian ini bertujuan untuk mengetahui pengaruh penerapan model pembelajaran two stay two stray (TS-TS) terhadap hasil belajar matematika ditinjau dari kecerdasan matematis-logis siswa kelas VIII MTsN 1 Kota Makassar. Jenis penelitian ini adalah quasi experimental dengan desain non equivalent control group design. Populasi dalam penelitian ini adalah seluruh siswa kelas VIII MTsN 1 Kota Makassar terdiri dari 13 kelas, yang berjumlah 513 siswa. Penentuan sampel dengan cara purposive sampling, kelas $\mathrm{VIII}_{6}$ sebagai kelas eksperimen sebanyak 40 siswa dan kelas $\mathrm{VIII}_{4}$ sebagai kelas kontrol sebanyak 40 siswa. Instrumen yang digunakan adalah tes hasil belajar matematika dan angket kecerdasan matematis-logis siswa. Teknik analisis data yang digunakan adalah analisis statistik deskriptif dan analisis statistik inferensial yaitu uji anova dua jalur. Berdasarkan hasil analisis statistik deskriptif diperoleh hasil belajar matematika siswa yang menerapkan model pembelajaran two stay two stray berada pada kategori tinggi dengan presentase sebesar $65 \%$ dan kecerdasan matematis-logis siswa yang menerapkan model two stay two stray berada pada kategori sedang dengan presentase sebesar 77,5\%. Berdasarkan analisis statistik inferensial menggunakan uji anova dua jalur diperoleh hasil bahwa tidak terdapat pengaruh penerapan model pembelajaran two stay two stray terhadap hasil belajar matematika ditinjau dari kecerdasan matematis-logis siswa kelas VIII MTsN 1 Kota Makassar.
\end{abstract}

Kata Kunci: Two Stay Two Stray, Hasil Belajar Matematika, Kecerdasan Matematis-Logis.

\section{Pendahuluan}

Belajar merupakan kebutuhan setiap manusia yang ingin berhasil dalam hidupnya. Dengan demikian, proses belajar terjadi melalui banyak cara baik disengaja maupun tidak disengaja yang berlangsung sepanjang waktu dan menuju pada suatu perubahan pada diri pembelajar. Belajar merupakan proses dalam diri individu yang berinteraksi dengan lingkungan untuk mendapatkan perubahan dalam perilakunya. Belajar adalah aktivitas mental/psikis yang berlangsung dalam interaksi aktif dengan lingkungan yang menghasilkan perubahan-perubahan dalam pengetahuan, keterampilan dan sikap (Ghufron \& Rini, 2014).

Hasil belajar seringkali digunakan sebagai ukuran untuk mengetahui seberapa jauh seseorang menguasai bahan yang sudah diajarkan. Menurut Winkel, hasil belajar adalah perubahan yang mengakibatkan manusia berubah dalam sikap dan tingkah lakunya (Purwanto, 2011). Jadi, hasil belajar adalah perubahan perilaku yang terjadi setelah mengikuti proses belajar mengajar sesuai dengan tujuan pendidikan.

Dalam hal ini, hasil belajar matematika merupakan suatu puncak proses belajar. Hasil belajar tersebut terjadi karena evaluasi oleh guru, demikian pula jika dikaitkan dengan belajar matematika maka hasil belajar matematika merupakan kemampuan yang dicapai siswa dalam memahami dan menerapkan konsep-konsep matematika setelah mengikuti proses belajar matematika. Jadi, yang dimaksud hasil belajar matematika adalah tingkat keberhasilan siswa menguasai bahan pelajaran matematika setelah mengikuti proses belajar mengajar.

Pada tingkat nasional, hasil belajar siswa pada pembelajaran matematika umumnya lebih rendah daripada mata pelajaran lainnya. Oleh karena itu, seorang guru dituntut untuk meningkatkan diri dengan berbagai kemampuan dan keterampilan, misalnya menguasai materi pelajaran dan keterampilan mengajar. Seorang guru profesional dalam melaksanakan tugas mengajarnya harus 
mampu menerapkan pendekatan, metode, teknik dan strategi pembelajaran yang efektif dan efisien agar tujuan pembelajaran dapat tercapai. Hasil belajar siswa dapat pula dipengaruhi oleh beberapa faktor, baik faktor dari dalam diri siswa maupun faktor dari luar diri siswa. Salah satu kendala dalam pembelajaran matematika yang dialami oleh siswa yaitu sikap negatif terhadap bidang studi matematika yang dianggap pelajaran yang sulit dipahami sehingga mereka tidak termotivasi untuk mempelajarinya. Oleh sebab itu, penerapan metode, strategi dan model yang bervariasi dalam pembelajaran matematika perlu dilakukan sehingga siswa tidak menganggap bahwa matematika adalah sesuatu yang perlu ditakuti karena mata pelajaran matematika menarik dan sangat dekat dengan kehidupan nyata.

Berdasarkan hasil wawancara salah seorang guru matematika di MTsN 1 Kota Makassar yang menerapkan kurikulum 2013 dengan nilai KKM 75 menunjukkan bahwa banyak siswa memiliki kekurangan dalam hal kemampuan penalaran matematis, siswa cenderung mampu menyelesaikan soal permasalahan pemahaman konsep tetapi masih membutuhkan banyak arahan dalam menyelesaikan soal yang berkaitan dengan permasalahan penalaran atau dalam pemecahan masalah. Permasalahan yang muncul juga adalah kurangnya kesiapan siswa dalam mengikuti kegiatan pembelajaran, kondisi siswa yang kurang memperhatikan ketika guru menerangkan pelajaran, serta terdapat beberapa siswa yang merasa malu untuk bertanya dan hanya sebagian siswa yang aktif ketika kegiatan pembelajaran berlangsung. Hal tersebut berpengaruh terhadap hasil belajar siswa. Selain itu, juga ditemukan bahwa siswa memiliki kecerdasan matematis-logis yang bervariasi. Berdasarkan observasi awal dari 80 siswa diperoleh kecerdasan matematis-logis pada kategori tinggi sebanyak 20\%, siswa dengan kecerdasan matematis-logis pada kategori sedang sebanyak 62,5\% dan siswa dengan kecerdasan matematis-logis pada kategori rendah sebanyak $17,5 \%$.

Penggunaan model pembelajaran kooperatif merupakan salah satu alternatif untuk dapat meningkatkan hasil belajar siswa. Pada model pembelajaran kooperatif diperlukan keterampilan dan kerja sama siswa dalam kelompoknya, melatih siswa dalam berfikir kritis sehingga kemampuan siswa dalam memahami materi pelajaran yang disampaikan dapat meningkat. Pembelajaran kooperatif merupakan aktivitas pembelajaran kelompok diorganisir oleh suatu prinsip bahwa pembelajaran harus didasarkan pada perubahan informasi secara sosial di antara kelompok-kelompok pembelajar yang di dalamnya setiap pembelajar bertanggung jawab atas pembelajarannya sendiri dan didorong untuk meningkatkan pembelajaran anggota-anggota yang lain (Huda, 2013). Model-model pembelajaran kooperatif adalah unik karena dalam pembelajaran kooperatif suatu struktur tugas dan penghargaan yang berbeda yang diberikan dalam mengupayakan pembelajaran siswa. Salah satu model pembelajaran kooperatif, yaitu teknik belajar mengajar dua tinggal dua tamu (two stay two stray) di singkat TS-TS (Shoimin, 2016).

Pembelajaran kooperatif tipe two stay two stray (TS-TS) memiliki ciri tersendiri. Ciri khas tipe ini adalah satu kelompok terdiri dari empat orang siswa, dalam prosesnya dua orang harus tetap di kelompok untuk menerangkan materi yang telah dipelajari dan dua orang siswa lainnya harus bertamu ke kelompok lain untuk mendengarkan dan mengkritisi keterangan yang disampaikan oleh siswa yang menetap dalam kelompok yang didatangi. Teknik belajar dua tinggal dua tamu (two stay two stray) dikembangkan oleh Spencer Kagan (1992). Struktur dua tinggal dua tamu memberi kesempatan kelompok untuk membagikan hasil dan informasi dengan kelompok lain. Model pembelajaran kooperatif dua tinggal dua tamu adalah dua orang tinggal di kelompok dan dua orang siswa bertamu ke kelompok yang lain. Dua orang tinggal bertugas memberikan informasi kepada 
tamu tentang hasil kelompoknya, sedangkan yang bertamu bertugas mencatat hasil diskusi kelompok yang dikunjungi (Shoimin, 2016).

Model pembelajaran two stay two stray merupakan teknik pembelajaran dengan struktur kelompok yang khas dua tinggal dua tamu yang bertujuan untuk siswa belajar kerja sama, bertanggung jawab, saling membantu memecahkan masalah dan saling mendorong untuk berprestasi serta melatih dapat bersosialisasi dengan baik. Langkah-langkah model pembelajaran two stay two stray (TS-TS) yaitu 1) siswa bekerja sama dengan kelompok berempat sebagaimana biasanya, guru memberikan tugas pada setiap kelompok untuk didiskusikan dan dikerjakan bersama, 2) setelah selesai dua anggota dari masing-masing kelompok diminta meninggalkan kelompoknya dan masingmasing bertamu ke anggota kelompok lain, 3) dua orang "tinggal"/stay dalam kelompok bertugas membagikan informasi dan hasil kerja mereka ke tamu dari kelompok lain dan"tamu"/stray memohon diri dan kembali ke kelompok yang semula dan melaporkan apa yang mereka temukan dari kelompok lain dan setiap kelompok lalu membandingkan dan membahas hasil pekerjaan mereka semua. Dengan adanya peran aktif dari semua siswa diharapkan pembelajaran menjadi lebih menyenangkan dan menumbuhkan minat belajar siswa serta meningkatkan hasil belajar matematika siswa. Khuzaini (2009) mengemukakan adanya peningkatan dari siklus I sebesar 58,5\% yang berada dalam kategori cukup kemudian berada pada kategori baik pada siklus II dengan persentase sebesar 85,25\% artinya bahwa model pembelajaran two stay two stray meningkatkan minat dan prestasi belajar matematika siswa.

Salah satu faktor lain yang mempengaruhi keberhasilan suatu proses pembelajaran adalah siswa itu sendiri. Pada diri siswa mempunyai karakteristik yang dapat mempengaruhi kegiatan belajar siswa yaitu latar belakang pengetahuan, taraf pengetahuan, gaya belajar, tingkat kematangan, lingkungan sosial ekonomi, kecerdasan, motivasi belajar dan lain-lain. Terkait dengan kecerdasan tidak terbatas pada IQ saja. Terdapat sembilan tipe kecerdasan dasar yang dimiliki setiap orang, yang selanjutnya disebut kecerdasan majemuk. Jenis kecerdasan yang banyak berhubungan dengan penilaian di sekolah atau akademik termasuk kemampuan dalam memahami konsep matematika adalah kecerdasan logika matematika (Prasetyo, Reza, \& Andriani, 2009).

Kajian tentang arti kecerdasan umumnya terkait dengan kemampuan seseorang dalam menggunakan aspek pemikiran (kognitif) untuk memecahkan berbagai masalah kehidupan yang dihadapi. Para ahli psikologi mengurunkan konsep kecerdasan dalam suatu istilah intelegensi (Afif, 2004). Intelegensi (kecerdasan) adalah istilah yang sulit untuk didefinisikan dan menimbulkan pemahaman yang berbeda-beda di antara ilmuan. Dalam pengertian yang populer, kecerdasan sering didefinisikan sebagai kemampuan mental umum untuk belajar dan menerapkan pengetahuan dalam memanipulasi lingkungan serta kemampuan untuk berpikir abstrak (Yaumi \& Nurdin, 2013). Santrock juga mengemukakan definisi tentang intelegensi yaitu keahlian memecahkan masalah, kemampuan untuk beradaptasi dan belajar dari pengalaman hidup sehari-hari (Rahman, 2014).

Kecerdasan matematik adalah kemampuan yang berkenaan dengan rangkaian alasan, mengenal pola-pola dan aturan. Kecerdasan ini merujuk pada kemampuan untuk mengeksplorasi pola-pola, kategori-kategori dan hubungan dengan memanipulasi objek atau simbol untuk melakukan percobaan dengan cara yang terkontrol dan teratur. Kecerdasan matematik disebut juga kecerdasan logis dan penalaran karena kemampuan dasar memecahkan masalah dengan memahami prinsipprinsip yang mendasari sistem kasual atau dapat memanipulasi bilangan, kuantitas dan operasi (Yaumi \& Nurdin, 2013). Berdasarkan uraian tersebut, maka dapat disimpulkan bahwa kecerdasan matematis-logis adalah salah satu jenis kecerdasan dari kecerdasan majemuk yang merupakan bagian 
dari kecerdasan intelektual yang sangat erat kaitannya dengan perhitungan, penalaran logis terhadap sesuatu hal dan bagaimana menyelesaikan suatu masalah dengan mengeksplorasi pola-pola yang sudah ada. Kecerdasan matematis-logis melibatkan keterampilan mengelola angka dengan baik atau kemahiran menggunakan penalaran atau logika dengan benar sehingga berpikir induktif, deduktif, rasional merupakan ciri yang melekat pada orang yang memiliki kecerdasan logika matematik yang membuat mereka sangat senang berhitung, bertanya dan melakukan eksperimen. Oleh karena itu, jika kecerdasan matematis logis siswa baik dalam pembelajaran maka sudah tentu kemampuan matematis ataupun hasil belajarnya juga baik. Kecerdasan matematik logis dan spasial berpengaruh terhadap hasil belajar matematika siswa kelas VII SMP Negeri 4 Sungguminasa Kabupaten Gowa. Sumbangsih pengaruh variabel kecerdasan matematik logis dan spasial 56\% sedangkan selebihnya $44 \%$ dipengaruhi oleh variabel lain yang tidak dimasukkan dalam penelitian ini (Anto, Ismail, \& Rahman, 2015). Berdasarkan beberapa penjelasan di atas, maka peneliti bermaksud untuk melakukan penelitian terkait pengaruh penerapan model pembelajaran two stay two stray (TS-TS) terhadap hasil belajar matematika ditinjau dari kecerdasan matematis-logis.

\section{Metode Penelitian}

Pendekatan yang digunakan pada penelitian ini adalah pendekatan kuantitatif dengan jenis penelitian yang digunakan adalah eksperimen semu (quasi eksperimental). Desain penelitian yang yang digunakan oleh peneliti adalah rancangan design factorial yaitu dengan memperhatikan adanya variabel moderator yang mempengaruhi perlakuan terhadap hasil. Penelitian ini dilakukan di MTsN 1 Kota Makassar. Jl. A. Pettarani No. 1A Makassar. Adapun populasi dalam penelitian ini adalah seluruh siswa kelas VIII MTsN 1 Kota Makassar yang berjumlah 513 orang.

Teknik pengambilan sampel yang digunakan adalah purposive sampling, teknik pengambilan sampel non random/acak dimana peneliti menentukan sampel dengan pertimbangan tertentu. Sehingga yang menjadi sampel dalam penelitian ini adalah kelas VIII $_{6}$ sebagai kelas eksperimen sebanyak 40 siswa dan kelas $\mathrm{VIII}_{4}$ sebagai kelas kontrol sebanyak 40 siswa yang dipilih karena berdasarkan informasi yang diperoleh dari guru pelajaran matematika kelas VIII bahwa kedua kelas tersebut juga memiliki kemampuan yang relatif sama.

Pengumpulan data pada penelitian ini dilakukan dengan teknik tes dan non tes. Data hasil belajar matematika siswa diperoleh melalui pemberian instrumen tes hasil belajar. Pada penelitian ini, dilakukan dua kali tes untuk setiap kelas, yaitu pretest dan posttest. Pretest dilakukan untuk mengetahui kemampuan awal hasil belajar peserta didik, sedangkan posttes dilakukan untuk mengetahui hasil belajar peserta didik setelah diberikan suatu pembelajaran. Instrumen pengumpulan data pada penelitian ini adalah essai dan angket. Berdasarkan hasil pretes dan posttest peserta didik dapat diketahui perkembangan hasil belajar matematikanya. Sedangkan data kecerdasan matematislogis diukur menggunakan angket.

Pengolahan data menggunakan analisis statistik deskriptif dan analisis inferensial. Analisis statistik deskriptif secara umum digunakan untuk mengetahui gambaran hasil belajar matematika dan kecerdasan matematis-logis. Sedang analisis statistik inferensial digunakan untuk menguji hipotesis penelitian dengan menggunakan uji anova dua jalur. Namun sebelumnya terlebih dahulu dilakukan uji prasyarat yaitu uji normalitas dan uji homogenitas.

\section{Hasil}

Berikut ini adalah tabel hasil analisis deskriptif data hasil belajar matematika yang menggunakan model pembelajaran two stay two stray pada siswa kelas VIII MTsN 1 Kota Makassar. 
Tabel 1. Deskripsi Pretest dan Posttest Hasil Belajar Kelas Eksperimen

\begin{tabular}{|c|c|c|c|c|c|}
\hline \multirow{2}{*}{ Kategori } & \multirow{2}{*}{ Interval } & \multicolumn{2}{|c|}{ Pretest } & \multicolumn{2}{|c|}{ Posttest } \\
\hline & & Frekuensi & Persentase $(\%)$ & Frekuensi & Persentase (\%) \\
\hline Sangat Rendah & $0-20$ & 0 & 0 & 0 & 0 \\
\hline Rendah & $21-40$ & 0 & 0 & 0 & 0 \\
\hline Sedang & $41-60$ & 0 & 0 & 0 & 0 \\
\hline Tinggi & $62-80$ & 36 & 90 & 26 & 65 \\
\hline Sangat Tinggi & $81-100$ & 4 & 10 & 14 & 35 \\
\hline \multicolumn{2}{|c|}{ Jumlah } & 40 & 100 & 40 & 100 \\
\hline
\end{tabular}

Berdasarkan tabel $1 \mathrm{di}$ atas dapat diketahui bahwa nilai pretest dan posttest siswa masingmasing berada pada kategori tinggi dengan persentase sebesar $90 \%$ dan $65 \%$, sedangkan pada kategori sangat tinggi pada kelas pretest sebesar $10 \%$ dan pada kelas posttest sebesar $35 \%$. Oleh karena itu, dapat disimpulkan bahwa hasil belajar matematika siswa pada kelas eksperimen mengalami peningkatan setelah diberikan perlakukan menggunakan model pembelajaran two stay two stray. Selanjutnya, hasil analisis deksriptif data hasil belajar matematika yang menggunakan model pembelajaran konvensional pada siswa kelas VIII MTsN 1 Kota Makassar.

Tabel 2. Deskripsi Pretest dan Posttest Hasil Belajar Kelas Kontrol

\begin{tabular}{|c|c|c|c|c|c|}
\hline \multirow{2}{*}{ Kategori } & \multirow{2}{*}{ Interval } & \multicolumn{2}{|c|}{ Pretest } & \multicolumn{2}{|c|}{ Posttest } \\
\hline & & Frekuensi & Persentase $(\%)$ & Frekuensi & Persentase (\%) \\
\hline Sangat Rendah & $0-20$ & 0 & 0 & 0 & 0 \\
\hline Rendah & $21-40$ & 0 & 0 & 0 & 0 \\
\hline Sedang & $41-60$ & 0 & 0 & 0 & 0 \\
\hline Tinggi & $62-80$ & 37 & 92,5 & 32 & 80 \\
\hline Sangat Tinggi & $81-100$ & 3 & 7,5 & 8 & 20 \\
\hline \multicolumn{2}{|c|}{ Jumlah } & 40 & 100 & 40 & 100 \\
\hline
\end{tabular}

Berdasarkan tabel 2 di atas dapat diketahui bahwa nilai pretest dan posttest siswa masingmasing berada pada kategori tinggi dengan persentase sebesar $92,5 \%$ dan $80 \%$, sedangkan pada kategori sangat tinggi pada kelas pretest sebesar $7.5 \%$ dan pada kelas posttest sebesar $20 \%$. Oleh karena itu, dapat disimpulkan bahwa hasil belajar matematika siswa pada kelas kontrol mengalami peningkatan setelah diberikan perlakuan menggunakan model pembelajaran two stay two stray. Selanjutnya, hasil analisis deksriptif data kecerdasan matematis-logis siswa menggunakan model pembelajaran two stay two stray pada siswa kelas VIII MTsN 1 Kota Makassar.

Tabel 3. Deskripsi Kecerdasan Matematis-Logis Siswa Kelas Eksperimen

\begin{tabular}{lccc}
\hline \multicolumn{1}{c}{ Kategori } & Interval & Frekuensi & Persentase (\%) \\
\hline Rendah & $x<72$ & 2 & 5 \\
Sedang & $72 \leq x<78$ & 31 & 77,5 \\
Tinggi & $x \leq 78$ & 7 & 17,5 \\
\hline & Jumlah & 40 & 100 \\
\hline
\end{tabular}


Berdasarkan hasil persentase kategorisasi kecerdasan matematis-logis siswa pada tabel 3 diketahui bahwa persentase terbesar berada pada kategori sedang yakni sebesar 77,5\%. Sedangkan kategori rendah memiliki persentase sebesar 5\% dan kategori tinggi sebesar 17,5\%. Oleh karena itu, dapat disimpulkan bahwa kecerdasan matematis-logis siswa pada kelas eksperimen rata-rata berada pada kategori sedang. Selanjutnya, hasil analisis deskriptif data kecerdasan matematis-logis siswa yang menggunakan model pembelajaran two stay two stray pada siswa kelas VIII MTsN 1 Kota Makassar.

Tabel 4. Deskripsi Kecerdasan Matematis-Logis Siswa Kelas Kontrol

\begin{tabular}{cccc}
\hline Kategori & Interval & Frekuensi & Persentase(\%) \\
\hline Rendah & $x<72$ & 2 & 5 \\
Sedang & $72 \leq x<78$ & 27 & 67,5 \\
Tinggi & $x \leq 78$ & 11 & 27,5 \\
\hline & Jumlah & 40 & 100 \\
\hline
\end{tabular}

Berdasarkan hasil persentase kategorisasi kecerdasan matematis-logis siswa pada table 4 diketahui bahwa persentase terbesar berada pada kategori sedang yakni sebesar 67,5\%, sedangkan kategori rendah memiliki persentase sebesar 5\% dan kategori tinggi sebesar 27,5\%. Oleh karena itu, dapat disimpulkan bahwa kecerdasan matematis-logis siswa pada kelas kontrol rata-rata berada pada kategori sedang. Selanjutnya, hasil analisis hasil analisis statistik inferensial menggunakan uji anova dua jalur.

Tabel 5 Uji Anova Dua Jalur (Hipotesis I)

\begin{tabular}{lccccc}
\hline \multicolumn{7}{c}{ Nilai Posttest } \\
\hline & Sum of Squares & Df & Mean Square & F & Sig. \\
\cline { 2 - 6 } Between Groups & 726.013 & 1 & 726.013 & 26.001 & .000 \\
Within Groups & 2177.975 & 78 & 27.923 & & \\
\hline Total & 2903.988 & 79 & & & \\
\hline
\end{tabular}

Berdasarkan tabel di atas, karena $\mathrm{F}_{0}=26,001>\mathrm{F}_{0,05}(1 ; 78)=3,96$, maka $\mathrm{H}_{0}$ ditolak dengan nilai Sig. $<\alpha=0,000<0,05$, sehingga dapat disimpulkan bahwa terdapat perbedaan yang signifikan antara penerapan model pembelajaran TSTS dan model pembelajaran konvensional terhadap hasil belajar matematika kelas VIII MTsN 1 Kota Makassar.

Tabel 6. Uji Tukey (Hipotesis II)

\begin{tabular}{ccc}
\hline Kelompok & Rata-rata & Sampel \\
\hline A1B1 & 86,14 & 7 \\
A1B2 & 81,19 & 31 \\
A1B3 & 82,50 & 2 \\
A2B1 & 74,82 & 11 \\
A2B2 & 76,59 & 27 \\
A2B3 & 76,50 & 2 \\
\hline & Jumlah & \\
\hline
\end{tabular}


Berdasarkan tabel 6, karena A1BI > A2B1 = 86,14 > 74,82, A1B2 > A2B2 = 81,19 > 76,59, $\mathrm{A} 1 \mathrm{~B} 3>\mathrm{A} 2 \mathrm{~B} 3=82,50>76,50$, maka dapat disimpulkan bahwa terdapat perbedaan antara kecerdasan matematis-logis tinggi, sedang dan rendah terhadap hasil belajar matematika siswa kelas VIII MTsN 1 Kota Makassar, sehingga $\mathrm{H}_{0}$ ditolak.

Tabel 7. Test of Between-Subjects Effects (Uji Hipotesis III)

\begin{tabular}{llcccc}
\hline \multicolumn{1}{c}{ Source } & $\begin{array}{c}\text { Type III Sum of } \\
\text { Squared }\end{array}$ & Df & Mean Squared & F & Sig. \\
\hline Corrected Model & $891.137^{\text {a }}$ & 5 & 178.227 & 6.552 & .000 \\
Interceot & 175158.576 & 1 & 175158.576 & $6.439 \mathrm{E} 3$ & .000 \\
Kelas & 368.926 & 1 & 368.926 & 13.563 & .000 \\
Kategori & 33.487 & 2 & 16.743 & .616 & .543 \\
Kelas * Kategori & 149.191 & 2 & 74.595 & 2.742 & .071 \\
Error & 2012.851 & 74 & 27.201 & & \\
Total & 503607.000 & 80 & & & \\
\hline Corrected Total & 2903.987 & 79 & & & \\
\hline
\end{tabular}

Berdasarkan tabel di atas karena $\mathrm{F}_{0}=2,742<\mathrm{F}_{0,05}(1 ; 78)=3,96$, maka $\mathrm{H}_{0}$ diterima dengan nilai Sig. $<\alpha=0,71>0,05$, sehingga dapat disimpulkan bahwa tidak terdapat pengaruh interaksi antara penerapan model pembelajaran TSTS terhadap hasil belajar matematika ditinjau dari kecerdasan matematis-logis siswa kelas VIII MTsN 1 Kota Makassar.

\section{Pembahasan}

Berdasarkan hasil belajar matematika siswa yang telah dijabarkan sebelumnya dan hasil dari observasi guru yang terkait serta hasil observasi selama proses pembelajaran berlangsung di kelas eksperimen dan kelas kontrol, maka peneliti menyimpulkan bahwa hasil belajar matematika siswa dengan menerapkan model pembelajaran two stay two stray mengalami peningkatan lebih tinggi dibanding siswa dengan model pembelajaran konvensional yang mengacu pada hasil posttest. Berdasarkan persentase kenaikan hasil belajar matematika yakni kelas eksperimen berada pada kategori tinggi dengan persentase kenaikan 10\%, sedangkan kelas kontrol berada pada kategori tinggi dengan persentase kenaikan $5 \%$.

Hasil deskripsi kecerdasan matematis-logis siswa yang telah dijabarkan sebelumnya, peneliti menyimpulkan bahwa kecerdasan matematis-logis siswa yang diterapkan model pembelajaran two stay two stray dan siswa yang diterapkan model pembelajaran konvensional berada pada kategori sedang, hasil tersebut sejalan dengan kondisi selama proses pengisian angket berlangsung pada materi teorema Phytagoras dimana kurangnya kejujuran siswa dalam mengisi angket yang terkait dengan kecerdasan matematis-logis siswa. Oleh karena itu, sebelum pengisian angket berlangsung terlebih dahulu dijelaskan bahwa tidak ada diskusi atau bertanya kepada teman serta menyontek dalam proses pengisian angket tersebut namun tidak dipungkiri bahwa selama proses pengisian angket berlangsung masih ada siswa yang bertanya kepada teman sebangkunya atau melihat jawaban temannya.

Hasil dari perhitungan anova diketahui bahwa terdapat perbedaan hasil belajar matematika siswa yang diterapkan model pembelajaran two stay two stray dan siswa yang diterapkan model pembelajaran konvensional. Berdasarkan hasil penelitian yang dilakukan oleh (Budiyono \& Sujadi, 2014) menunjukkan bahwa model pembelajaran kooperatif tipe two stay two stray memberikan 
prestasi belajar yang lebih baik dibanding model pembelajaran kooperatif tipe NHT dan model pembelajaran langsung. Model pembelajaran kooperatif tipe NHT memiliki prestasi yang sama baiknya dengan model pembelajaran langsung. Mengacu pada penelitian terdahulu maka disimpulkan bahwa model pembelajaran two stay two stray lebih baik dibanding model pembelajaran konvensional. Dengan didukung salah satu kelebihan diterapkannya model two stay two stray siswa lebih aktif, siswa memiliki peran masing-masing dalam menyelesaikan tugas yang diberikan sehingga siswa menyimak materi dengan baik, siswa lebih berani mengungkapkan pendapatnya dan lebih percaya diri.

Berdasarkan hasil analisis uji Tukey, diketahui bahwa terdapat perbedaan hasil belajar matematika siswa ditinjau dari kecerdasan matematis-logis siswa kelas VIII SMP MTsN 1 Kota Makassar. Hal ini sejalan dengan pendapat Nurhidayat (2016) yang menyatakan bahwa berdasarkan analisis uji Tukey koefisien rata-rata hasil belajar matematika siswa yang diajar dengan menggunakan model PBI pada kategorisasi kecerdasan logis matematis tinggi, sedang dan rendah lebih tinggi daripada hasil belajar matematika siswa yang diajar menggunakan model pembelajaran langsung pada kategorisasi kecerdasan logis matematis tinggi, sedang dan rendah. Ciri-ciri dinamika perkembangan psikologi remaja awal yaitu; mulai menerima kondisi dirinya, berkembangnya cara berpikir, menyadari bahwa setiap manusia memiliki perbedaan potensi, proporsi tubuh yang semakin proporsional, tindakan masih kekanakan, akibat ketidakstabilan emosi dan periode yang sulit dan kritis.

Hasil dari perhitungan anova dua jalur, diketahui bahwa tidak terdapat pengaruh interaksi penerapan model pembelajaran two stay two stray terhadap hasil belajar matematika ditinjau dari kecerdasan matematis-logis siswa kelas VIII MTsN 1 Kota Makassar. Biyarti, Riyadi dan Sujadi (2013) juga mengemukakan bahwa tidak terdapat interaksi antara penggunaan model pembelajaran pada materi logaritma. Dengan kata lain bahwa pada setiap kategori kecerdasan matematis logis, model pembelajaran TPS, TPSPK dan pembelajaran langsung memberikan hasil belajar matematika yang sama baik. Berdasarkan hasil perhitungan anova, diperoleh model pembelajaran dan kecerdasan matematis-logis berpengaruh nyata, sedangkan interaksinya berpengaruh tidak nyata menunjukkan bahwa fungsi model pembelajaran dan kecerdasan matematis-logis saling menekan pengaruh masigmasing. Setiap penelitian mempunyai objek yang berbeda serta peneliti menyadari bahwa adanya keterbatasan dalam penelitian, yaitu peneliti tidak dapat mengendalikan faktor-faktor lain selama proses pembelajaran berlangsung salah satunya adalah persoalan waktu, dimana persoalan waktu sesuai dengan salah satu kekurangan model pembelajaran two stay two stray yaitu model pembelajaran ini membutuhkan waktu yang lama.

\section{Kesimpulan}

Hasil belajar matematika siswa yang diajar menggunakan model TS-TS dan menggunakan model konvensional pada kategori tinggi. Kecerdasan matematis-logis siswa yang diajar dengan menggunakan model pembelajaran two stay two stray dan konvensional berada pada kategorisasi sedang. Terdapat pengaruh signifikan antara model pembelajaran TS-TS dan model pembelajaran konvensional terhadap hasil belajar matematika siswa kelas VIII MTsN 1 Kota Makassar. Terdapat perbedaan antara kecerdasan matematis-logis tinggi, sedang, dan rendah terhadap hasil belajar matematika siswa kelas VIII MTsN 1 Kota Makassar. Tidak terdapat pengaruh interaksi antara model pembelajaran dan kecerdasan matematis-logis terhadap hasil belajar matematika siswa kelas VIII MTsN 1 Kota Makassar. 


\section{Daftar Pustaka}

Afif, A. (2004). Psikologi Guru. Makassar: Alauddin University Press.

Anto, M. I., Ismail, M. I., \& Rahman, U. (2015). Pengaruh Kecerdasan Matematik Logis dan Kecerdasan Spasial terhadap Hasil Belajar Matematika Siswa Kelas VII SMP Negeri 4 Sungguminasa Kabupaten Gowa. Jurnal MAPAN: Jurnal Matematika Dan Pembelajaran, 3(2), 191.

Budiyono, Z., \& Sujadi, I. (2014). Ekspermentasi Model Pembelajaran Kooperatif Tipe Two Stay Two Stray Dan Number Head Together Pada Materi Pokok Fungsi Ditinjau dari Kecerdasan Interpersonal Siswa Kelas VIII SMP Negeri Se-Kota Surakarta. Jurnal Elektronik Pembelajaran Matematika, 2(2), 128.

Ghufron, M. N., \& Rini, R. (2014). Gaya Bahasa Kajian Teoritik. Yogyakarta: Pustaka Pelajar.

Huda, M. (2013). Model-model Pengajaran dan Pembelajaran Isu-isu Metodis dan Paradigma. Malang: Pustaka Pelajar.

Khuzaini, N. (2009). Meningkatkan Minat dan Prestasi Belajar Matematika dengan Model Pembelajaran Kooperatif Tipe Two Stay Two Stray Pokok Bahasan Trigonometri Siswa Kelas Xb MAN Godean Yogyakarta. UIN Sunan Kalijaga.

Nurhidayat A, M. (2016). Pengaruh Penerapan Model Pembelajaran Problem Based Instruction (PBI) terhadap Hasil Belajar Peserta Didik Kelas VII Ditinjau dari Kecerdasan Logis Matematis Pada Mts. As'adiyah Kampiri Kab. Wajo.

Prasetyo, Reza, J., \& Andriani, Y. (2009). Multiply Your Multiple Intelligences. Yogyakarta: Andi Yogyakarta.

Purwanto. (2011). Evaluasi Hasil Belajar. Yogyakarta: Pustaka Pelajar.

Rahman, U. (2014). Memahami Psikologi dalam Pendidikan Teori dan Aplikasi. Makassar: Alauddin University Press.

Shoimin, A. (2016). 68 Model Pembelajaran Inovatif dalam Kurikulum 2013. Yogyakarta: Ar-Ruzz Media.

Tunggu, B., Riyadi, \& Sujadi, I. (n.d.). Eksperimentasi Model pada Materi Logaritma Ditinjau dari Kecerdasan Matematis Logis Siswa Kelas X pada Sekolah Menengah Atas di Kabupaten Cilacap Tahun Pelajaran 2012/2013. Jurnal Elektronik Pembelajaran Matematika, 1(7), 690699.

Yaumi, M., \& Nurdin, I. (2013). Pembelajaran Berbasis Kecerdasan Jamak (Multiple Intellegence) Mengidentifikasi dan Mengembangkan Multi talenta Anak. Jakarta: Prenada Media Group. 